\title{
Phosphorus Restriction Prevents Parathyroid Gland Growth High Phosphorus Directly Stimulates PTH Secretion In Vitro
}

\author{
Eduardo Slatopolsky, Jane Finch, Masashi Denda, Cindy Ritter, Min Zhong, Adriana Dusso, Paul N. MacDonald, \\ and Alex J. Brown \\ Department of Internal Medicine, Renal Division, Washington University School of Medicine, St. Louis, Missouri 63110; \\ and *St. Louis University School of Medicine, Department of Pharmacology and Physiology, St. Louis, Missouri 63103
}

\begin{abstract}
Dietary phosphorus $(\mathrm{P})$ restriction is known to ameliorate secondary hyperparathyroidism in renal failure patients. In early renal failure, this effect may be mediated by an increase in $1,25-(\mathrm{OH})_{2} \mathrm{D}_{3}$, whereas in advanced renal failure, $P$ restriction can act independent of changes in 1,25$(\mathrm{OH})_{2} \mathrm{D}_{3}$ and serum ionized calcium (ICa). In this study, we examined the effects of dietary $\mathrm{P}$ on serum PTH, PTH mRNA, and parathyroid gland (PTG) hyperplasia in uremic rats. Normal and uremic rats were maintained on a low $(0.2 \%)$ or high $(0.8 \%)$ P diet for 2 mo. PTG weight and serum PTH were similar in both groups of normal rats and in uremic rats fed the $0.2 \% \mathrm{P}$ diet. In contrast, there were significant increases in serum PTH $(130 \pm 25$ vs. $35 \pm 3.5 \mathrm{pg} / \mathrm{ml}$, $P<0.01)$, PTG weight $(1.80 \pm 0.13$ vs. $0.88 \pm 0.06 \mu \mathrm{g} / \mathrm{gram}$ of body weight, $P<0.01)$, and PTG DNA $(1.63 \pm 0.24$ vs. $0.94 \pm 0.07 \mu \mathrm{g}$ DNA/gland, $P<0.01)$ in the uremic rats fed the $0.8 \% \mathrm{P}$ diet as compared with uremic rats fed the $0.2 \% \mathrm{P}$ diet. Serum ICa and 1,25-(OH $)_{2} \mathrm{D}_{3}$ were not altered over this range of dietary $P$, suggesting a direct effect of $P$ on PTG function. We tested this possibility in organ cultures of rat PTGs. While PTH secretion was acutely $(30 \mathrm{~min})$ regulated by medium calcium, the effects of medium $P$ were not evident until $3 \mathrm{~h}$. During a 6-h incubation, PTH accumulation was significantly greater in the $2.8 \mathrm{mM} \mathrm{P}$ medium than in the $0.2 \mathrm{mM} P$ medium $(1,706 \pm 215$ vs. $1,033 \pm 209 \mathrm{pg} / \mu \mathrm{g}$ DNA, $P<0.02$ ); the medium ICa was $1.25 \mathrm{mM}$ in both conditions. Medium P did not alter PTH mRNA in this system, but cycloheximide $(10 \mu \mathrm{g} / \mathrm{ml})$ abolished the effect of $P$ on PTH secretion. Thus, the effect of $P$ is posttranscriptional, affecting PTH at a translational or posttranslational step. Collectively, these in vivo and in vitro results demonstrate a direct action of $\mathbf{P}$ on PTG function that is independent of ICa and 1,25-(OH $)_{2} \mathrm{D}_{3}$. (J. Clin. Invest. 1996. 97:2534-2540.) Key words: phosphorus $\bullet$ hyperparathyroidism • calcitriol • calcium • uremia
\end{abstract}

\footnotetext{
Address correspondence to Eduardo Slatopolsky, M.D., Department of Internal Medicine, Renal Division, Chromalloy American Kidney Center, Washington University School of Medicine, 660 South Euclid Avenue, Box 8129, St. Louis, MO 63110-1093. Phone: 314-362-7205; FAX: 314-362-7875.

Received for publication 17 November 1995 and accepted in revised form 12 March 1996.
}

J. Clin. Invest.

(C) The American Society for Clinical Investigation, Inc. 0021-9738/96/06/2534/07 \$2.00

Volume 97, Number 11, June 1996, 2534-2540

\section{Introduction}

The two major factors responsible for the development of secondary hyperparathyroidism in chronic renal insufficiency are phosphorus retention and low levels of $1,25-(\mathrm{OH})_{2} \mathrm{D}_{3}$. Several investigators have provided evidence for a role of phosphorus retention in the pathogenesis of secondary hyperparathyroidism, but the mechanism of this effect remains unclear. In normal humans (1) and in patients with moderate renal insufficiency (2), restriction of dietary phosphorus increases the production rate of $1,25-(\mathrm{OH})_{2} \mathrm{D}_{3}$, which in turn decreases the level of immunoreactive PTH. However, this mechanism may not be operative in advanced renal insufficiency because the decrease in renal mass may limit the production of 1,25$(\mathrm{OH})_{2} \mathrm{D}_{3}(3-5)$. Lopez-Hilker and collaborators (6) demonstrated in dogs with advanced renal insufficiency and severe secondary hyperparathyroidism that a gradual reduction of phosphorus in the diet was accompanied by a significant decrease in the levels of PTH without changes in ICa or 1,25$(\mathrm{OH})_{2} \mathrm{D}_{3}$. Although these data clearly demonstrated that the effect of phosphorus on PTH secretion was independent of changes in serum ICa and $1,25-(\mathrm{OH})_{2} \mathrm{D}_{3}$, they did not evaluate the role of phosphorus on parathyroid cell growth or establish if phosphorus directly affected the synthesis or secretion of PTH. Thus, the current studies were performed to further understand the role of phosphorus in the pathogenesis of secondary hyperparathyroidism. Studies were performed in vivo in rats with chronic renal insufficiency and in vitro with dispersed bovine parathyroid cells, primary culture of bovine parathyroid cells, and intact parathyroid glands from normal rats.

\section{Methods}

Renal insufficiency was induced in a group of female Sprague-Dawley rats by $5 / 6$ nephrectomy. The procedure entails the ligation of most of the branches of the left renal artery followed by right nephrectomy. The animals were divided into four groups: $(a)$ normal rats fed a $0.5 \%$ calcium and $0.2 \%$ phosphorus diet; $(b)$ uremic rats fed a $0.5 \%$ calcium and $0.2 \%$ phosphorus diet; $(c)$ normal rats fed a $1 \%$ calcium and $0.8 \%$ phosphorus diet; and $(d)$ uremic rats fed a $1 \%$ calcium and $0.8 \%$ phosphorus diet. The $0.2 \%$ phosphorus diet is considered to be a low phosphorus diet, and the $0.8 \%$ phosphorus diet is considered to be a high phosphorus diet, although these two values are at the lower and upper limits of normal phosphorus intake for the rat. The amount of calcium in the $0.8 \% \mathrm{P}$ diet was increased to $1 \%$ to prevent the development of hypocalcemia, while the amount of calcium in the $0.2 \%$ $\mathrm{P}$ diet was decreased to $0.5 \%$ to avoid hypercalcemia. After 2 mo on the above diets, the rats were killed and blood was obtained for ICa, phosphorus, creatinine, $\mathrm{PTH}$, and $1,25-(\mathrm{OH})_{2} \mathrm{D}_{3}$. The parathyroid glands were removed and weighed. DNA, protein, and pre-pro PTH mRNA were measured.

Preparation of dispersed cells of bovine parathyroid glands. Parathyroid cells were prepared according to the method of MacGregor et al. 
(7) with minor modifications. Briefly, parathyroid glands were trimmed of extraneous fatty tissue, sliced with a Stadie-Riggs tissue slicer (Thomas Scientific, Swedesboro, NJ) and placed in DME (HG)/Ham's F-12 culture medium (50/50) containing $2.5 \mathrm{mg} / \mathrm{ml}$ collagenase (Boehringer Mannheim, Indianapolis, IN) and $0.5 \mathrm{mM}$ total calcium. The suspension (1 gram of tissue per $10 \mathrm{ml}$ of media) was agitated in a shaking water bath at $37^{\circ} \mathrm{C}$ for 90 min and periodically aspirated through a large-bore hole cut in an Eppendorf pipette tip attached to a $60-\mathrm{ml}$ syringe. The digested tissue was filtered through four-ply gauze, and newborn calf serum was added to a final concentration of $4 \%$. The cells were washed three times with chilled, serumfree culture medium, DME (HG)/Ham's F-12 medium (50/50), containing $1 \mathrm{mM}$ total calcium, $15 \mathrm{mM}$ Hepes, $100 \mathrm{IU} / \mathrm{ml}$ penicillin, 100 $\mu \mathrm{g} / \mathrm{ml}$ streptomycin, $5 \mu \mathrm{g} / \mathrm{ml}$ insulin, $2 \mathrm{mM}$ glutamine, $1 \%$ nonessential amino acids, $1 \mathrm{mg} / \mathrm{ml}$ bovine serum albumin, and $5 \mu \mathrm{g} / \mathrm{ml}$ holotransferrin. The cells were kept on ice.

Treatment media were prepared as follows. Monobasic sodium phosphate, $\mathrm{pH} 7.5$, was added to final concentrations of $0.1,1.0$, or 3.0 $\mathrm{mM}$ to phosphate-free DME (HG)/Ham's F-12 medium (50/50) containing the supplements listed above. Cells were resuspended in treatment media at $0.5 \times 10^{6}$ cells $/ \mathrm{ml}$ and placed in uncapped $7-\mathrm{ml}$ polypropylene scintillation vials $(1 \mathrm{ml}$ cells/vial). The vials were gently agitated at $37^{\circ} \mathrm{C}$ in a $5 \% \mathrm{CO}_{2}$ incubator for $4 \mathrm{~h}$. Cells were pelleted, and the supernatant was stored at $-20^{\circ} \mathrm{C}$ until PTH analysis could be performed. Cell pellets were stored at $-20^{\circ} \mathrm{C}$ and subsequently analyzed for DNA following the method of LePecq and Paoletti (8). PTH was assayed using antibody $\mathrm{CH} 9$, which recognized intact, midregion, and carboxy-terminal fragments of PTH. Details of the recognition characteristics of the antisera and the RIA methodology have been described previously (9).

PTH secretion in primary culture of bovine parathyroid cells. Dispersed cells were resuspended in medium (described above) containing $4 \%$ newborn calf serum and placed in 12 -well plates at 80,000 cells $/ \mathrm{cm}^{2}$. After $24 \mathrm{~h}$, the medium was replaced with serum-free medium. On the third day in culture, cells were treated with medium containing $0.1,1.0$, or $3.0 \mathrm{mM} \mathrm{P}$ for another $72 \mathrm{~h}$. Medium was replenished every $24 \mathrm{~h}$. To determine the rate of PTH secretion, cells were washed twice and then incubated in fresh medium for $3 \mathrm{~h}$ at $37^{\circ} \mathrm{C}$ in $5 \% \mathrm{CO}_{2}$. The medium was collected for PTH analysis as described above.

Cellular protein in each sample was determined by sonicating the cells in $1 \mathrm{mM} \mathrm{NaOH}$ and assaying with a protein assay kit (Bio Rad Laboratories, Richmond, CA).

Measurement of parathyroid gland weight. To evaluate parathyroid gland weight, parathyroid glands were removed using microsurgical techniques and weighed on a CAHN C-31 microbalance (Cahn Instruments, Inc., Cerritos, CA). Coefficient of variance was $1.5 \%$.

Parathyroid secretion by rat parathyroid glands. Rat parathyroid gland pairs were excised from surrounding thyroid tissue and immediately placed on ice in 12-well plates containing the appropriate ex- perimental medium prepared as described above for the studies in bovine cells to contain 0.2 or $2.8 \mathrm{mM} \mathrm{P}$ and the designated concentration of $\mathrm{Ca}$. Glands were transferred to a $5 \% \mathrm{CO}_{2}$ incubator and incubated at $37^{\circ} \mathrm{C}$ for $30 \mathrm{~min}$. Glands were then transferred to wells containing $2 \mathrm{ml}$ of fresh media and incubated at $37^{\circ} \mathrm{C}$ with $5 \% \mathrm{CO}_{2}$. Media were sampled at 1,3 , and $5 \mathrm{~h}$ for PTH determinations and at $5 \mathrm{~h}$ for ICa levels. After $5 \mathrm{~h}$ the glands were washed with medium three times and $1 \mathrm{ml}$ of fresh medium was added. After $1 \mathrm{~h}$ the medium was removed for ICa and PTH determinations and the glands were placed in $0.5 \mathrm{ml}$ of buffer containing $0.1 \mathrm{M} \mathrm{NaCl}$ and $0.1 \mathrm{M}$ Tris- $\mathrm{HCl}$ and frozen at $-20^{\circ} \mathrm{C}$ for DNA analysis (7).

Analysis of pre-pro PTH $m R N A$. On the third day of culture, the medium from bovine parathyroid cell monolayers was replaced with defined medium containing either $0.1,1.0$, or $3.0 \mathrm{mM}$ P. The monolayers received fresh medium every $24 \mathrm{~h}$. Cells were lysed at various times with RNAzol (Cinna/Biotecx, Friendswood, TX) and total RNA was isolated and analyzed by Northern blot analysis as described previously (10).

Parathyroid gland pairs from rats were homogenized in $250 \mu \mathrm{l}$ RNAzol (Cinna Biotecx) in a microfuge tube using a plastic pestle. Total RNA was isolated as directed by the manufacturer and analyzed by a ribonuclease protection assay. Riboprobes for rat PTH were produced using SP6 RNA polymerase and a template containing bases $122-461$ of the coding sequence of the rat PTH gene (provided by Jeremiah Morrissey, Ph.D., Washington University). A riboprobe for rat $\beta 2$-actin was made using T7 RNA polymerase and an RT-PCR cDNA cloned into pCR II (provided by Alan Dean, Ph.D., Washington University). The sizes of the riboprobes and protected fragments were 380 and 339 for PTH and 280 and 250 for $\beta$-actin, respectively.

RNA from each parathyroid gland pair $(20 \%$ of the total) was dissolved in $10 \mu \mathrm{l}$ hybridization buffer $(80 \%$ formamide, $50 \mathrm{mM}$ Pipes, $\mathrm{pH}$ 6.4, $400 \mathrm{mM} \mathrm{NaCl}, 1 \mathrm{mM}$ EDTA) and mixed with the ${ }^{32} \mathrm{P}$ labeled riboprobes for PTH and $\beta$-actin and dissolved in $30 \mu \mathrm{l}$ hybridization buffer. To reduce background, the specific activity of the riboprobes for PTH and $\beta$-actin was adjusted to obtain labeled protected fragments with similar radioactivity. After hybridization at $45^{\circ} \mathrm{C}$ for $16 \mathrm{~h}$, the samples were mixed with $150 \mu \mathrm{l}$ of ribonuclease digestion mixture consisting of $2 \mu \mathrm{g} / \mathrm{ml}$ ribonuclease T1 in $10 \mathrm{mM}$ Tris- $\mathrm{HCl}, \mathrm{pH}$ $7.5,300 \mathrm{mM} \mathrm{NaCl}$, and $5 \mathrm{mM}$ EDTA. Proteinase $\mathrm{K}(50 \mu \mathrm{g})$ and $20 \mu \mathrm{l}$ of $5 \%$ SDS were added, and the samples were incubated for $15 \mathrm{~min}$ at $37^{\circ} \mathrm{C}$. After phenol/chloroform extraction and ethanol precipitation, the samples were resolved on a $5 \%$ polyacrylamide gel in $8.3 \mathrm{M}$ urea, $100 \mathrm{mM}$ Tris-borate, and $2 \mathrm{mM}$ EDTA. The dried gel was exposed to $\mathrm{x}$-ray film for $16 \mathrm{~h}$, and the bands were quantified by scanning densitometry.

Analytical determinations. ICa was measured by an ICa-specific electrode (model 1CA-1; Radiometer, Copenhagen, Denmark). Plasma phosphorus and creatinine were determined using an autoan-

Table I. Blood Chemistries

\begin{tabular}{|c|c|c|c|c|}
\hline \multirow{3}{*}{ Diet } & \multicolumn{2}{|c|}{ Normal } & \multicolumn{2}{|c|}{ Uremic } \\
\hline & $\mathrm{Ca} 0.5 \%$ & $\mathrm{Ca} 1.0 \%$ & Ca $0.5 \%$ & Ca $1.0 \%$ \\
\hline & $\mathrm{P} 0.2 \%$ & $\mathrm{P} 0.8 \%$ & $\mathrm{P} 0.2 \%$ & P $0.8 \%$ \\
\hline Number of rats & 15 & 15 & 31 & 29 \\
\hline Body weight (grams) & $238 \pm 2.7$ & $227 \pm 3.5$ & $230 \pm 1.7$ & $235 \pm 3.1$ \\
\hline Serum creatinine $(\mathrm{mg} / \mathrm{dl})$ & $0.59 \pm 0.02$ & $0.58 \pm 0.03$ & $1.26 \pm 0.05^{*}$ & $126 \pm 0.04 *$ \\
\hline BUN (mg/dl) & $16.8 \pm 0.46$ & $17.5 \pm 0.79$ & $41 \pm 1.8^{*}$ & $38 \pm 2.1 *$ \\
\hline $\mathrm{ICa}(\mathrm{mg} / \mathrm{dl})$ & $4.74 \pm 0.03$ & $4.67 \pm 0.03$ & $4.63 \pm 0.03$ & $4.7 \pm 0.03$ \\
\hline Phosphorus (mg/dl) & $3.09 \pm 0.18$ & $4.31 \pm 0.16$ & $4.43 \pm 0.21$ & $5.74 \pm 0.44^{\ddagger}$ \\
\hline $1,25-(\mathrm{OH})_{2} \mathrm{D}_{3}(\mathrm{pg} / \mathrm{ml})$ & $20 \pm 1.1$ & $21.9 \pm .79$ & $24.1 \pm 1.38$ & $22.2 \pm 1.46$ \\
\hline
\end{tabular}

$B U N$, blood urea nitrogen. ${ }^{\ddagger} P<0.01$ when compared with all other groups. $* P<0.001$ when compared with normal rats. 
alyzer (COBAS-MIRA Plus, Branchburg, NJ). Intact PTH was measured by an immunoradiometric assay specific for intact rat PTH (Nichols Institute, San Juan Capistrano, CA). 1,25-(OH $)_{2} \mathrm{D}_{3}$ was measured using the extraction procedure developed by Hollis (11) and the radioreceptor assay of Reinhardt et al. (12). The diets were purchased from Dyets, Inc. (Bethlehem, PA).

Statistical analysis. All data are expressed as mean \pm SEM. Oneway ANOVA was used for comparisons between groups.

\section{Results}

The effect of dietary P restriction on the development of secondary hyperparathyroidism in uremic rats was determined after 2 mo of renal insufficiency.

Table I illustrates the body weights and serum chemistries in uremic and normal control rats fed diets containing $0.2 \% \mathrm{P}$ or $0.8 \% \mathrm{P}$ for the 2 -mo period. As expected, the serum creatinine and blood urea nitrogen increased in the uremic animals. ICa and 1,25- $(\mathrm{OH})_{2} \mathrm{D}_{3}$ were the same in all four groups of animals. Serum phosphorus increased in the animals ingesting the high phosphorus diet, but was significantly elevated only in the uremic animals $(P<0.01)$.

Uremic rats fed the $0.2 \%$ phosphorus diet had serum PTH levels that did not differ from either group of normal rats $(P=$ NS). However, serum PTH was significantly increased in uremic rats fed the $0.8 \%$ phosphorus diet compared with uremic rats receiving the low $\mathrm{P}$ diet $(130 \pm 25$ vs. $35 \pm 3.5 \mathrm{pg} / \mathrm{ml}, P<$ 0.001) (Fig. 1). Fig. 2 shows a positive correlation between serum phosphorus and PTH levels in the rats fed the $0.8 \%$ phosphorus diet $(n=29, P<0.0001, r=0.859)$. In uremic rats fed the $0.2 \%$ phosphorus diet, the weight of the parathyroid glands did not differ from either group of normal rats $(P=$ NS). On the other hand, in uremic rats fed the $0.8 \%$ phosphorus diet, parathyroid gland weight increased from $0.882 \pm 0.05$ to $1.80 \pm 0.13 \mu \mathrm{g} / \mathrm{gram}$ of body weight $(P<0.001)$ (Fig. 3$)$. To further characterize the growth of the parathyroid glands, DNA and protein were determined. These results are shown in Fig. 4. Parathyroid gland DNA and protein were substantially greater $(P<0.01)$ in the uremic rats fed the $0.8 \%$ phosphorus diet $(n=10)$, when compared with the normal rats $(n=7)$ fed the same diet. The magnitudes of the increases in DNA and protein in this group were similar, indicating that hyperplasia was responsible for the increase in the size of the parathyroid glands. Moreover, there was a direct correlation between parathyroid gland DNA and serum PTH in uremic rats fed a $0.2 \%$ $(n=13)$ and $0.8 \%(n=10)$ phosphorus diet. Regression analysis indicated a correlation coefficient of 0.739 and a $P<0.001$ $(n=23)$ (Fig. 5). On the other hand, the correlation between intact PTH and serum ICa was not statistically significant $(r=$ 0.089). To further characterize the changes in the parathyroid glands, steady state pre-pro PTH mRNA levels were measured (Fig. 6). No difference in the PTH/actin mRNA ratio was detected $(n=8)$. Thus, these in vivo studies show a significant effect of phosphorus restriction on PTH secretion and parathyroid cell growth which is independent of the levels of ICa and $1,25-(\mathrm{OH})_{2} \mathrm{D}_{3}$.

Studies were then conducted in vitro to determine if phosphorus has a direct effect on parathyroid cell function. Initial studies examined dispersed bovine parathyroid cells. During a 30 min incubation period, media phosphorus $(0.1,1.0$, or 3.0 $\mathrm{mM})$ did not affect the secretion of PTH $(n=6)$. On the other hand, when ICa was increased from 0.2 to $3.0 \mathrm{mM}$, PTH secre-

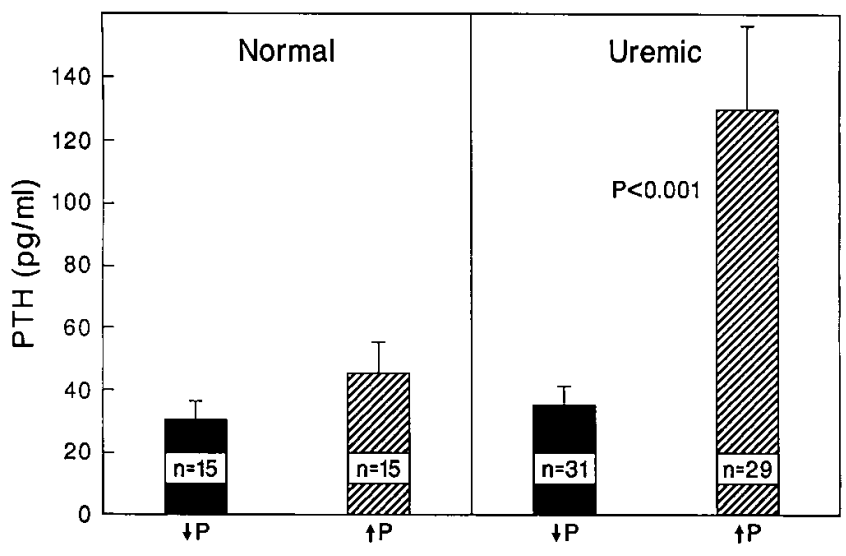

Figure 1. Intact serum rat PTH in normal $(n=15)$ and uremic $(n=$ 30) rats fed a low (closed bars) $0.2 \%$ or a high (dashed bars) $0.8 \%$ phosphorus diet.

tion decreased by $40 \%$. Subsequent studies were performed in primary culture of bovine parathyroid cells. Varying medium phosphorus $(0.1,1.0$, or $3.0 \mathrm{mM})$ for 24,48 , or $72 \mathrm{~h}$ had no effect on PTH secretion $(n=26)$ or PTH/GAPDH mRNA $(n=$ 8) (data not shown). Moreover, phosphorus did not modify the suppressive effect of $1,25-(\mathrm{OH})_{2} \mathrm{D}_{3}$ on PTH secretion $(n=6)$.

Since the preparation of dispersed bovine parathyroid cells and primary culture of bovine parathyroid cells alter the normal parathyroid gland structure, we decided to perform studies using intact rat parathyroid glands. When freshly dissected parathyroid glands from normal rats were incubated for $1 \mathrm{~h}$ with high or low Ca medium, the secretion of PTH decreased by $\sim 40 \%$ by increasing Ca from 0.2 to $3 \mathrm{mM}$. Increasing phosphorus in the medium from 0.2 to $2.8 \mathrm{mM}$, however, did not change PTH secretion (Fig. 7, $n=8$ ) during a 1-h incubation. Therefore, we followed PTH secretion in rat parathyroid organ cultures for up to $6 \mathrm{~h}$. Fig. 8 shows the accumulation of PTH in medium of parathyroid glands incubated on a low $(0.2$ $\mathrm{mM})$ or high $(2.8 \mathrm{mM})$ phosphorus diet. After $3 \mathrm{~h}$ of incubation, there was a statistically greater amount of PTH secreted into the media of the glands incubated with $2.8 \mathrm{mM}$ phospho-

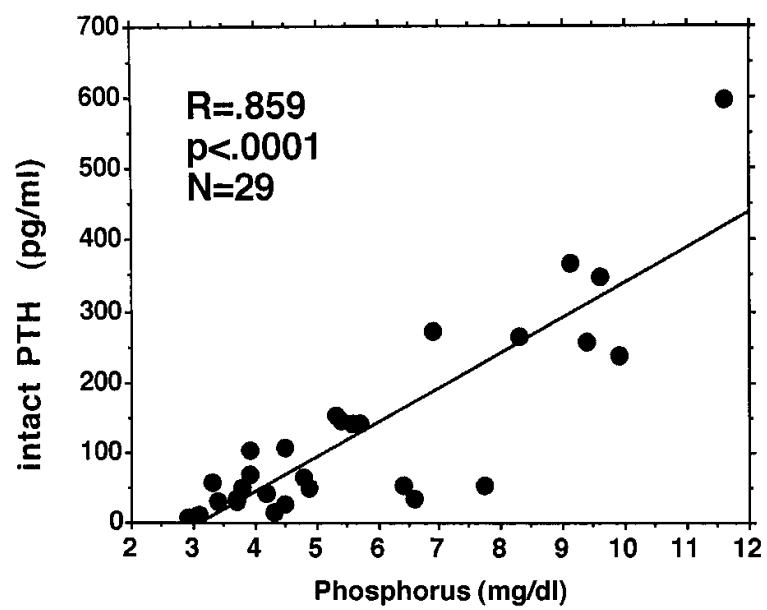

Figure 2. Regression analysis between serum PTH (pg/ml) and serum phosphorus in the rats fed the $0.8 \%$ phosphorus diet. 


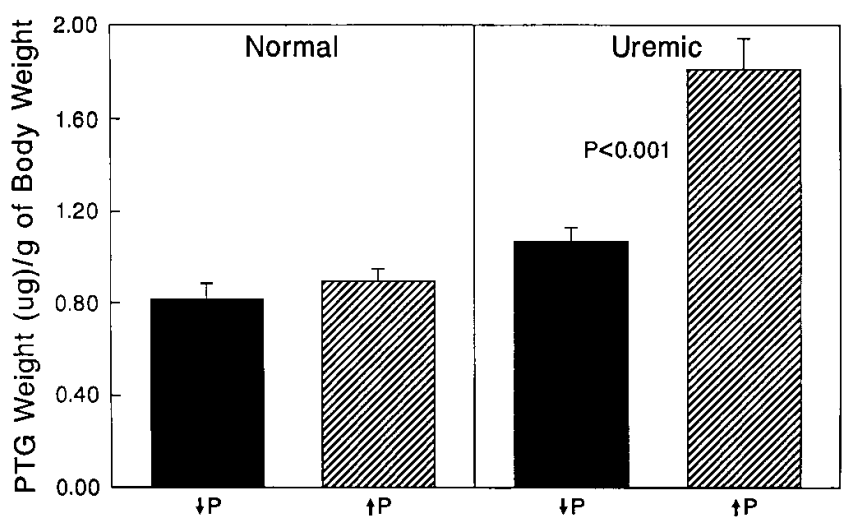

Figure 3. Parathyroid gland weight ( $\mu \mathrm{g} / \mathrm{gram}$ of body weight) normal $(n=15)$ and uremic $(n=30)$ rats fed a low (closed bars) or high (dashed bars) phosphorus diet.

rus. At the end of $6 \mathrm{~h}$, the amount of PTH secreted was $1,033 \pm 209 \mathrm{pg} / \mu \mathrm{g}$ DNA in the $0.2 \mathrm{mM}$ phosphorus versus $1,706 \pm 215 \mathrm{pg} / \mu \mathrm{g}$ DNA in the medium containing $2.8 \mathrm{mM}$ phosphorus $(P<0.05)$. To determine if the lower values for PTH secretion on the low phosphorus medium were due to an alteration in the secretory mechanism due to phosphorus depletion, the glands were incubated in media containing low $(0.2 \mathrm{mM})$ phosphorus and normal $(1.25 \mathrm{mM})$ calcium for a period of $4 \mathrm{~h}$ and then incubated in either low phosphorus, low calcium $(0.2 \mathrm{mM})$ medium, or a low phosphorus, high calcium (2.6 $\mathrm{mM})$ medium for an additional $2 \mathrm{~h}$ (Fig. 9). PTH secretion
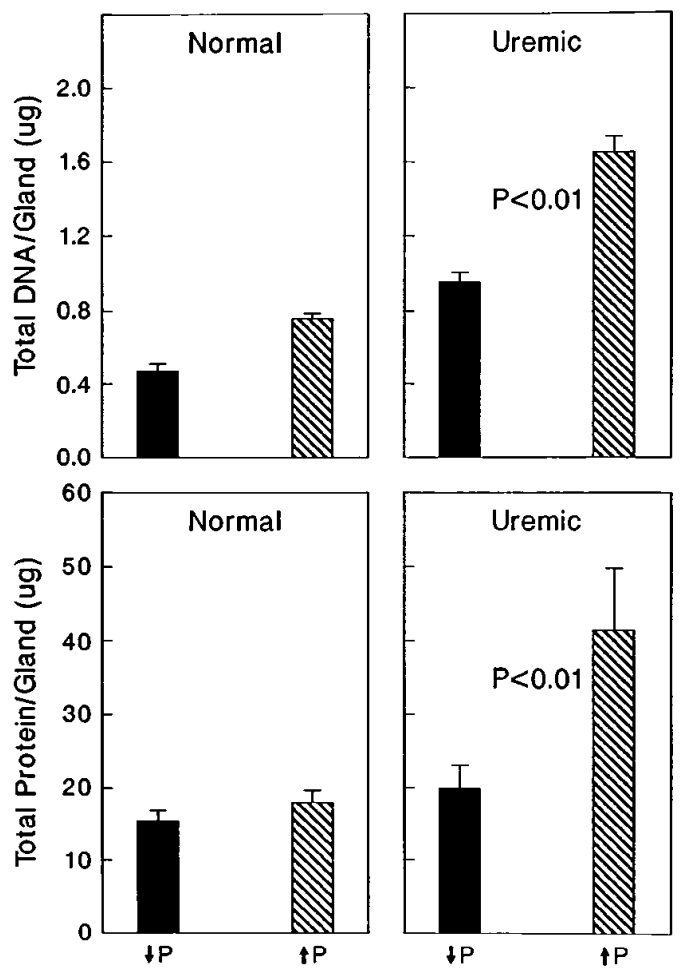

Figure 4. Parathyroid gland DNA and protein in normal $(n=7)$ and uremic rats $(n=10)$ fed a low (closed bars) or a high (dashed bars) phosphorus diet.

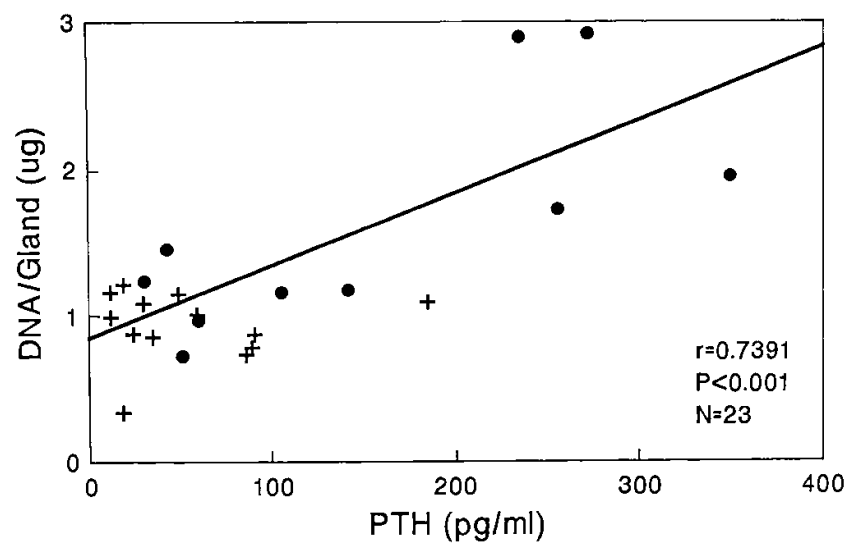

Figure 5. Regression analysis between PTH $(\mathrm{pg} / \mathrm{ml})$ and DNA $(\mu \mathrm{g} /$ gland $)$ in the uremic rats fed the low $(+)(n=13)$ or high $(\bullet)(n=$ 10) phosphorus diet.

was substantially greater in the low calcium medium (702.8 \pm $164 \mathrm{pg} / \mu \mathrm{g}$ DNA) than in the medium containing high calcium $(50.8 \pm 13.2 \mathrm{pg} / \mu \mathrm{g}$ DNA). Thus, these results clearly indicate that after $4 \mathrm{~h}$ of incubation in a low phosphorus medium the parathyroid glands were still able to respond appropriately to calcium. To determine if protein synthesis was critical in the increase in PTH secretion in a high phosphorus medium, rat parathyroid glands were incubated in a medium containing cycloheximide $(10 \mu \mathrm{g} / \mathrm{ml})$. The addition of cycloheximide prevented the increase in PTH secretion induced by the high phosphorus medium $(n=6)$ (results not shown).

To confirm that cycloheximide did not produce irreversible cellular damage after a 6-h incubation, glands were washed several times and then exposed to high or low calcium medium. They responded properly to the concentrations of cal-

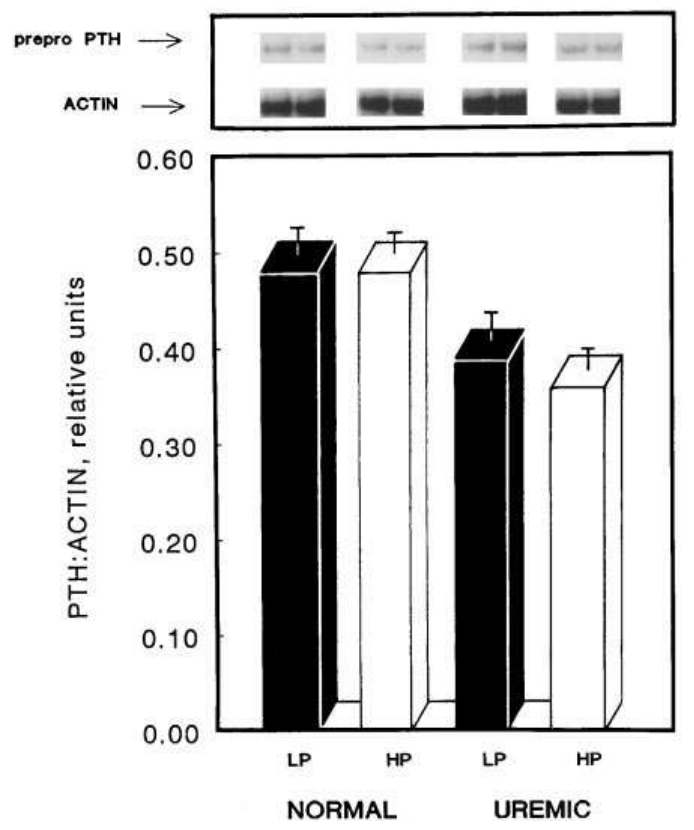

Figure 6. PTH/actin mRNA ratio in parathyroid glands from normal and uremic rats fed a low (closed bars) $(n=8)$ or high (open bars) $(n=8)$ phosphorus diet. 


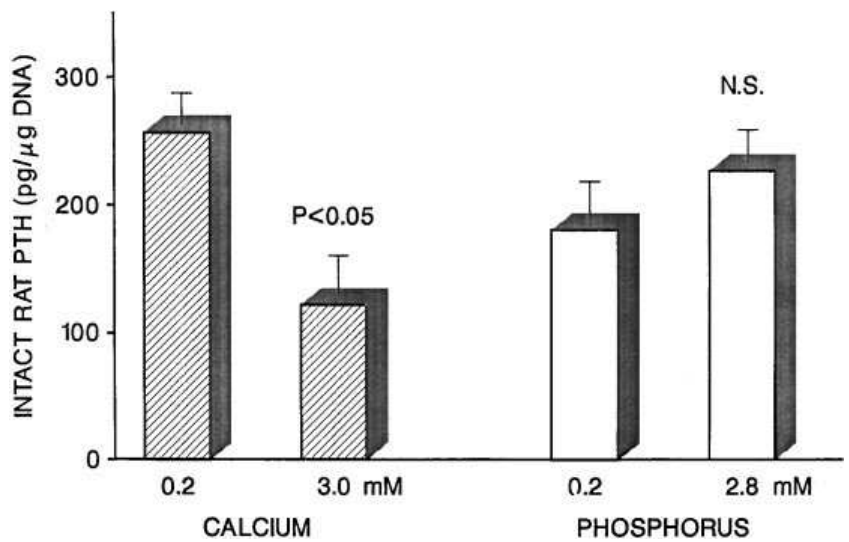

Figure 7. Intact PTH from media after 1-h of incubation of normal rat parathyroid glands in media containing low or high calcium $(\mathrm{P}=1$ $\mathrm{mM})$ or low or high phosphorus $(\mathrm{Ca}=1.25 \mathrm{mM})$.

cium in the medium (results not shown). To determine if the increased synthesis of PTH was at the mRNA level, a ribonuclease protection assay was performed using RNA extracted from rat parathyroid glands incubated in 0.2 or $2.8 \mathrm{mM} \mathrm{P}$. Phosphorus did not influence the PTH/actin mRNA $(n=8)$ (results not shown).

\section{Discussion}

In 1937, in a classic paper, Truman G. Drake, Fuller Albright, and Benjamin Castleman (13) studied parathyroid hyperplasia in rabbits produced by parenteral phosphate administration. They concluded "the findings support the hypothesis that retention of phosphate is the cause of parathyroid hyperplasia in cases of renal insufficiency; it will require further studies to

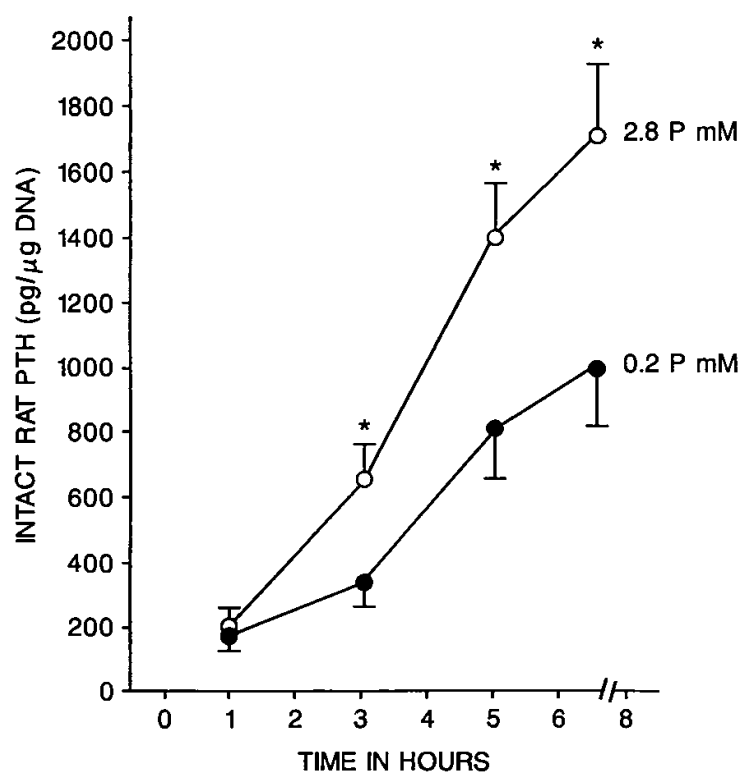

Figure 8. Time course for PTH secretion by normal intact rat parathyroid glands, incubated in a low $(0.2 \mathrm{mM})(\bullet)(n=8)$ or high $(2.8$ $\mathrm{mM})(\bigcirc)(n=8)$ phosphorus in the media $(P<0.05)$. The effects of phosphorus were not evident until $3 \mathrm{~h}$.

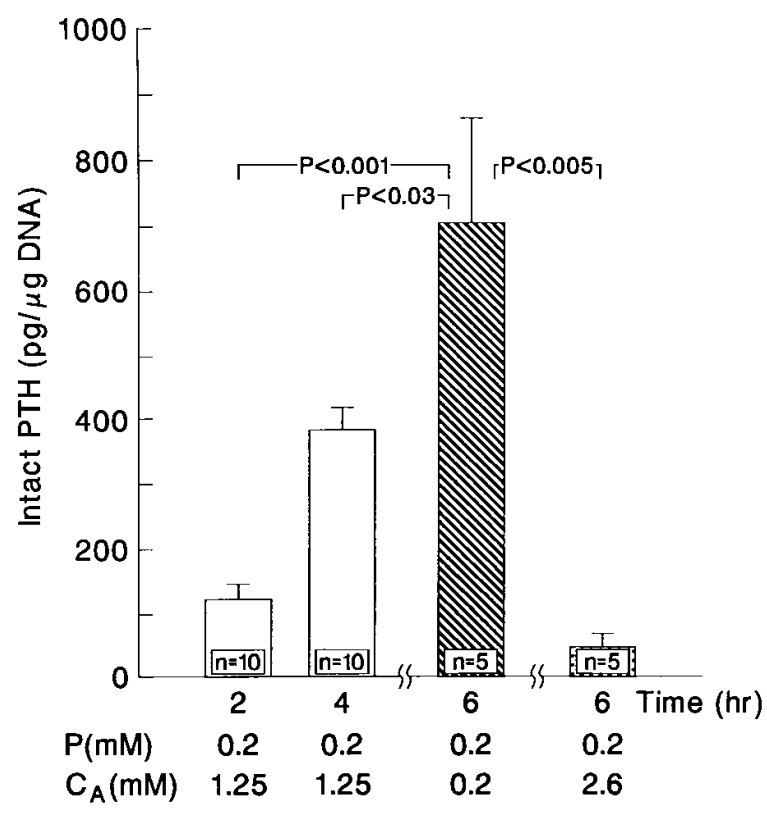

Figure 9. PTH secretion by normal rat parathyroid glands incubated in a $0.2 \mathrm{mM} \mathrm{P}, 1.25 \mathrm{mM}$ Ca medium, in 2 and $4 \mathrm{~h}$ (open bars). After $4 \mathrm{~h}$ parathyroid glands were incubated either in $0.2 \mathrm{mM} \mathrm{Ca}$ (dashed bar) or $2.6 \mathrm{mM} \mathrm{Ca}$ (dotted bar) and PTH secreted in $2 \mathrm{~h}$ was measured.

show whether the hyperphosphatemia causes hyperplasia directly, or indirectly, by producing hypocalcemia." A number of studies have attributed the effect of phosphate on hyperparathyroidism to secondary alterations in serum ICa and 1,25$(\mathrm{OH})_{2} \mathrm{D}_{3}(1,2,14-19)$. While it is clear that phosphorus intake can regulate these two modulators of parathyroid gland function, phosphate may also exert a direct action of the parathyroid glands.

We found that mild phosphate restriction $(0.2 \%$ P vs. $0.8 \%$ $P$ diet) could prevent hyperparathyroidism in uremic rats. The higher phosphate diet increased PTH levels and produced hyperplasia of the parathyroid glands. The effect of dietary $\mathrm{P}$ intake could not be attributed to differences in ICa or 1,25$(\mathrm{OH})_{2} \mathrm{D}_{3}$ since they were the same in the two groups. The hyperparathyroidism produced by the higher $\mathrm{P}$ diet was not accompanied by an increase in pre-pro PTH mRNA, suggesting that the high PTH levels were due to increased gland size and posttranscriptional enhancement of PTH synthesis and/or secretion.

We investigated this apparently direct action of phosphorus in vitro. We found no effect of phosphorus on PTH secretion in dispersed or cultured bovine parathyroid cells. Thus, it appears that in either short-term (studies with dispersed cells) or in primary cultures of bovine parathyroid cells, phosphorus does not affect PTH secretion. We speculate that cell-cell contact or cell-matrix interactions may be necessary for the effect of phosphorus on PTH secretion. This concept is supported by our studies with intact parathyroid glands of normal rats. Short-term experiments $(1 \mathrm{~h})$ (Fig. 7) indicated that changing the concentration of phosphorus from 0.2 to $2.8 \mathrm{mM}$ did not affect PTH secretion, but the glands responded to changes in extracellular calcium under these conditions. Long-term incubations of the parathyroid glands revealed an effect of high phosphorus by $3 \mathrm{~h}$. This time requirement suggests that phos- 
phorus alters the rate of PTH synthesis rather than secretion. Addition of cycloheximide abolished the enhanced accumulation of PTH in the medium, indicating that new protein synthesis is mandatory for phosphorus to increase the secretion of PTH.

We did not see an effect of phosphorus on PTH mRNA after a 6-h incubation of intact parathyroid glands in high $\mathrm{P}$ media, which is consistent with our findings in vivo. In contrast, in a recent paper Kilav et al. (20) also demonstrated an effect of phosphorus on PTH, but they found that high dietary phosphorus led to an increase in PTH mRNA. However, the two experimental conditions were not identical. Their studies were performed in normal, 3-wk-old rats while our studies were done using adult uremic rats. Their low phosphorus diet produced significant increases in both $1,25-(\mathrm{OH})_{2} \mathrm{D}_{3}$ and serum calcium; therefore subsequent studies were done in second generation rats fed a vitamin D-deficient diet to prevent differences in 1,25D and calcium. These dissimilar experimental conditions could account for disparate PTH mRNA results. Regardless of the precise mechanism(s) of action by which dietary phosphorus restriction suppresses PTH secretion, both studies demonstrated a significant independent effect of phosphorus in PTH synthesis/secretion. Our studies have also demonstrated an effect of phosphorus on parathyroid cell growth. Similar results were reported recently by Yi et al. (21) and Naveh-Many et al. (22). In addition, our studies demonstrated in vitro a direct effect of phosphorus on PTH synthesis/secretion. This effect seems to be posttranscriptional. This finding has important clinical implications. We and others (23) have observed in dialysis patients that the control of secondary hyperparathyroidism by $1,25-(\mathrm{OH})_{2} \mathrm{D}_{3}$ is lost when the patients develop hyperphosphatemia. It is possible that persistent hyperphosphatemia in dialysis patients increases the rate of parathyroid cell growth. In view of the studies of Fukuda et al. (24) which demonstrated that the larger the parathyroid glands the lower the number of vitamin $\mathrm{D}$ receptors and the recent observations of Arnold et al. (25) of monoclonal transformation in hyperplastic parathyroid glands from patients with severe secondary hyperparathyroidism and hyperphosphatemia, our results emphasize the critical need to control phosphorus in uremic patients.

Also, it is not known currently how phosphorus induces PTH synthesis or parathyroid gland hyperplasia. We should emphasize that the conditions of our experiments are not identical to those seen in clinical uremia where exposure to high phosphate for many years may affect calcium and vitamin D metabolism. Denda et al. (26) demonstrated that the effect of phosphorus on parathyroid cell growth in uremic rats is very rapid; $90 \%$ of the growth observed after 2 mo of renal failure occurs in the first $3 \mathrm{~d}$. Potentially, the participation of protooncogenes like c-fos, c-jun, and PRAD-1 (27-29) may play a role in the growth of the parathyroid glands. Also, it is not yet known how phosphorus increases PTH synthesis in the parathyroid glands and enhances the rate of PTH secretion. This effect is not acute and, therefore, apparently does not occur directly through the signaling pathway for calcium. It may, through a slower process, alter the responsiveness to calcium. These possibilities are under investigation.

In conclusion, we have demonstrated that dietary phosphorus restriction not only prevents secondary hyperparathyroidism independent of serum ICa and 1,25- $(\mathrm{OH})_{2} \mathrm{D}_{3}$ but prevents parathyroid cell growth. Moreover, we also have demonstrated for the first time a direct action of phosphorus in vitro to increase the rate of PTH synthesis. The effect seems to be posttranscriptional. Further studies at the molecular level are necessary to precisely define the mechanism of action of phosphorus in the development of secondary hyperparathyroidism in chronic renal failure.

\section{Acknowledgments}

The authors wish to express their appreciation to Sue Viviano for her assistance in the preparation of this manuscript.

This work was supported in part by National Institute of Diabetes and Digestive and Kidney Diseases grants DK-09976, DK-30178, and DK-07126.

\section{References}

1. Portale, A.A., B.P. Halloran, and J.C. Morris. 1989. Physiologic regulation of the serum concentration of 1,25-dihydroxyvitamin $\mathrm{D}_{3}$ by phosphorus in normal men. J. Clin. Invest. 83:1494-1499.

2. Portale, A.A., B.E. Booth, B.P. Halloran, and R.C. Morris, Jr. 1984. Effect of dietary phosphorus on circulating concentrations of 1,25-dihydroxy-vitamin D and immunoreactive parathyroid hormone in children with moderate renal insufficiency. J. Clin. Invest. 73:1580-1589.

3. Lucas, P.A., R.C. Brown, J.S. Woodhead, and G.A. Coles. 1986. 1,25-dihydroxycholecalciferol and parathyroid hormone in advanced chronic renal failure: effect of simultaneous protein and phosphorus restriction. Clin. Nephrol. 25:7-10.

4. Schaefer, K., C.M. Erley, D. von Herrath, and G. Stein. 1989. Calcium salts of ketoacids as a new treatment strategy for uremic hyperphosphatemia. Kidney Int. 36:S136-S139.

5. Aparicio, M., C. Combe, M.H. Lafage, V. De Precigout, L. Potaux, and J.L. Bourchet. 1994. In advanced renal failure, dietary phosphorus restriction reverses hyperparathyroidism independent of the levels of calcitriol. Nephron. 63:122-123.

6. Lopez-Hilker, S., A. Dusso, N. Rapp, K.J. Martin, and E. Slatopolsky. 1990. Phosphorus restriction reverses hyperparathyroidism in uremia independent of changes in calcium and calcitriol. Am J. Physiol. 259:F432-F437.

7. MacGregor, R.R., M.P. Sarras, A. Houle, and D.V. Cohn. 1983. Primary monolayer cell culture of bovine parathyroids: effects of calcium, isoproterenol and growth factors. Mol. Cell. Endocrinol. 30:313-328.

8. LePecq, J.B., and C. Paoletti. 1966. A new fluorometric method for RNA and DNA determination. Anal. Biochem. 17:100-107.

9. Hruska, K.A., R. Kopelman, W.E. Rutherford, S. Klahr, and E. Slatopolsky. 1975. Metabolism of immunoreactive parathyroid hormone in the dog. The role of the kidney and the effects of chronic renal disease. J. Clin. Invest. 56:3948.

10. MacDonald, P.N., C. Ritter, A. Brown, and E. Slatopolsky. 1994. Retinoic acid suppresses PTH secretion and pre-pro PTH mRNA levels in bovine parathyroid cell culture. J. Clin. Invest. 93:725-730.

11. Hollis, B.W. 1986. Assay of circulating 1,25-dihydroxyvitamin $\mathrm{D}_{3}$ involving a novel single extraction and purification procedure. Clin. Chem. 32:20202023.

12. Reinhardt, T.A., R.L. Horst, V. Orf, and B.W. Hollis. 1984. A microassay for 1,25-dihydroxyvitamin D not requiring high performance liquid chromatography: application to clinical studies. J. Clin. Endocrinol. \& Metab. 58:91-98.

13. Drake, T.G., F. Albright, and B. Castleman. 1937. Parathyroid hyperplasia in rabbits produced by parenteral phosphate administration. J. Clin. Invest. 16:203-206.

14. Slatopolsky, E., S. Caglar, J.P. Pennell, D.D. Taggart, J. M. Canterbury, E. Reiss, and N. S. Bricker. 1971. On the pathogenesis of hyperparathyroidism in chronic experimental renal insufficiency in the dog. J. Clin. Invest. 50:492-499.

15. Slatopolsky, E., W.E. Rutherford, P.E. Hoffsten, I.O. Elkan, H.R. Butcher, and N. S. Bricker. 1972. Non-suppressible secondary hyperparathyroidism in chronic progressive renal disease. Kidney Int. I:43-51.

16. Slatopolsky, E., S. Caglar, L. Gradowska, J. Canterbury, E. Reiss, and N.S. Bricker. 1972. On the prevention of secondary hyperparathyroidism in experimental chronic renal disease using "proportional reduction" of dietary phosphorus intake. Kidney Int. 2:147-151.

17. Slatopolsky, E., and N.S. Bricker. 1973. The role of phosphate restriction in the prevention of secondary hyperparathyroidism in chronic renal disease. Kidney Int. 4:141-149.

18. Rutherford, W.E., P. Bordier, P. Marie, K. Hruska, H. Harter, A. Greenwalt, J. Blondin, J. Haddad, N. Bricker, and E. Slatopolsky. 1977. Phosphate control and 25-hydroxy-cholecalciferol administration in preventing experimental renal osteodystrophy in the dog. J. Clin. Invest. 60:332-341.

19. Reiss, E., M.J. Canterbury, and M.A. Bercovitz. 1970. The role of phosphate in the secretion of parathyroid hormone in man. J. Clin. Invest. 49:2146- 
2149 .

20. Kilav, R., J. Silver, and T. Naveh-Many. 1995. Parathyroid hormone gene expression in hypophosphatemic rats. J. Clin. Invest. 96:327-333.

21. Yi, H., M. Fukagawa, H. Yamato, M. Kumagai, T. Watanabe, and K. Kurokawa. 1995. Prevention of enhanced parathyroid hormone secretion, synthesis and hyperplasia by mild dietary phosphorus restriction in early chronic renal failure in rats: possible direct role of phosphorus. Nephron. 70:242-248.

22. Naveh-Many, T., R. Rahamimo, N. Livni, and J. Silver, 1995. Parathyroid cell proliferation in normal and chronic renal failure rats. The effects of calcium, phosphate and vitamin D. J. Clin. Invest. 96:1786-1793.

23. Quarles, L.D., D.A. Yaohay, B.A. Carroll, C.E. Spritzer, S.A. Minda, D. Bartalomay, and B. deBaugh. 1994. Prospective trial pulse oral versus intravenous calcitriol treatment of hyperparathyroidism in ESRD. Kidney Int. 45: 1710-1721.

24. Fukuda, N., H. Tanaka, Y. Tominaga, M. Fukagawa, K. Kurokawa, and Y. Seino. 1993. Decreased 1,25-dihydroxyvitamin $\mathrm{D}_{3}$ receptor density is associated with a more severe form of parathyroid hyperplasia in chronic uremic pa- tients. J. Clin. Invest. 92:1436-1443.

25. Arnold, A., M. F. Brown, P. Ureña, R. Gaz, E. Sarfati, and T. Drüeke. 1995. Monoclonality of parathyroid tumors in chronic renal failure and primary parathyroid hyperplasia. J. Clin. Invest. 95:2047-2053.

26. Denda, M., J. Finch, and E. Slatopolsky. 1995. Parathyroid hyperplasia and secondary hyperparathyroidism develop rapidly in experimental uremic rats. J. Bone Miner. Res. 10:S276.

27. Arnold, A., H.G. Kim, R.D. Gaza, R.L. Eddy, Y. Fukushima, M.G. Byers, T.B. Shows, and H.M. Kronenberg. 1989. Molecular cloning and chromosome mapping of DNA rearranged with the parathyroid hormone gene in parathyroid adenoma. J. Clin. Invest. 83:2034-2040.

28. Motokura, T., T. Bloom, T.B. Kim, H. Juppner, J.V. Ruderman, H.M. Kronenberg, and A. Arnold. 1991. A novel cyclin encoded by a bcl1-candidate oncogene. Nature (Lond.). 350:512-515.

29. Rosenberg, C., H.G. Kim, T.B. Shows, H.M. Kronenberg, and A. Arnold. 1991. Rearrangement and over-expression of D11S287E, a candidate oncogene on chromosome 11q13 in benign parathyroid tumors. Oncogene. 6:449-453. 